\title{
Protein and Carbohydrate Digesting Capability of Syzigium Seed Powder in the Tissue Homogenate of Mid Gut in the Fifth Instar of Silkworm, Bombyx mori (L) Race: Bivoltine Cross Breed [(CSR6 x CSR26) x CSR2 x CSR27)]
}

\author{
Dipali Anil Ajage, Amruta Sanjay Tambe, Supriya Sunil Pawar \\ and Vitthalrao B. Khyade*
}

Science Association, Shardabai Pawar Mahila Mahavidyalaya, Shardanagar Tal. Baramati Dist. Pune - 413115, India

*Corresponding author

\section{Keywords \\ Bombyx mori (L), Mid gut homogenate, Midgut protease, Midgut amylase, Syzigium cumuni (L)}

Article Info

Accepted:

15 December 2018 Available Online: 10 January 2019

\section{A B S T R A C T}

Four different concentrations (10.0 ppm; $20.0 \mathrm{ppm} ; 40.0 \mathrm{ppm}$ and $50.0 \mathrm{ppm})$ of the aqueous solution of seed powder of Syzigium cumini (L) concentrations was used to treat the leaves of mulberry and fed to the fifth instar larvae of bivoltine, crossbreed silkworm, Bombyx mori (L) Race: Bivoltine Cross Breed [(CSR6 x CSR26) x CSR2 x CSR27)] for first four days of fifth instar larvae. The larvae fed with untreated and water treated leaves were also maintained. The midgut enzyme (protease and amylase) bioassays were carried out on fifth day. The velocity of biochemical reaction catalyzed by mid gut protease and midgut amylase in larvae fed with untreated mulberry leaves was found measured 02.593 units and 5.547 units respectively. The midgut protease activity in larvae fed with mulberry leaves treated with various concentrations $(10.0 \mathrm{ppm} ; 20.0 \mathrm{ppm} ; 40.0 \mathrm{ppm}$ and $50.0 \mathrm{ppm}$ ) of the aqueous solution of seed powder of Syzigium cumini (L) was found measured $3.217 ; 4.339 ; 4.476$ and 5.793 units respectively. There was 24 to 123 percent increase in the mid gut protease activity through Syzigium treatment. The midgut amyase activity in experimental group larvae in attempt was found measured $6.864 ; 10.148$; 10.319 and 10.483 units respectively. There was 23 to 88 percent increase in the mid gut protease activity through Syzigium treatment. The contents of seed powder of Syzigium cumini (L) serve to improve the digestibility and exert the influence of efficient metabolism in the fifth instar larvae of silkworm, Bombyx mori (L). The Syzigium seed powder treatment may gear overall biochemical constituency of silkworm larvae, through the significant improvement in the velocity of mid gut enzyme catalyzed biochemical

\section{Introduction}

Silkworm like insects are herbivores. The life of insect herbivores is interlinked with metabolites in plants. The metamorphosis in insects is said to be in the orchestrate progression. The insect metamorphosis is closely interlinked with plant metabolites. According to Bowers et al., (1966) the chemical constituents of plants (Roots; Stems; Leaves and Fruits) could have been the factors of growth and metamorphosis for 
insects. The plant eating insects are able to avoid poor quality food. That is to say, the insects are able to select food from variety available for them. The larvae of silkworm, Bombyx mori (L) are monophagous. They are feeding exclusively on the leaves of mulberry Morus alba (L). For the purpose of getting qualitative silk cocoons, it is essential to fortify either the quality of food (mulberry leaves) appetite of larval instars of silkworm, Bombyx mori (L). According to Murugan and George (1992), the factors responsible for influencing the growth, development and subsequent physiology of body of silkworm larvae include: quality of nutrition, that is to say the biochemical status of nutrients in the food (Leaves of mulberry, Morus alba L); quantity of hormones (hormonal level) in the body and the conditions of climate (environmental conditions). Each and every element in body of larva is primarily derived from it's source of food material. The leaves of mulberry, Morus alba (L) are exclusive source of nutrients for the life of larval instars of silkworm, Bombyx mori (L). The leaves of mulberry, Morus alba (L) are containing the nutrients and many stimulants for the life of larval instars of silkworm, Bombyx mori (L) (Ito, 1960,1961; Nayar and Fraenkel, 1962; Ito et al., 1964; Ito and Hyashiya, 1965). The quality of the nutrition (leaves of mulberry, Morus alba L.) serves a lot to accelerate the growth, metamorphosis in larval instars of silkworm, Bombyx mori (L). The entire credit of life of silkworm, Bombyx mori (L) goes to the nutrients in the leaves of mulberry, Morus alba (L). Therefore, the leaves of mulberry, Morus alba (L) forms the physiological foundation for sericulture. The leaves of mulberry are the mulberry, Morus alba (L). The leaves of mulberry, Morus alba (L) biochemically constituted with proteins, lipids, carbohydrates (Murali, 1992) and minerals (Subramanyam Reddy, 1992). The biochemical profile of the leaves of mulberry, Morus alba (L.) exert influence on the corresponding diversity of larval mid-gut enzymes capable of hydrolyzing the biocompounds in the body of larval instars of silkworm, Bombyx mori (L). The proteins; lipids; carbohydrates (glycogen) are stored in the body tissues of larval instars of silkworm, Bombyx mori (L) especially, the fat bodies.

There is variation in the food consumption in phytophagous insects. This may be for varied biochemical processes, ultimately for successful adaptations (Slansky, 1982). It has been suggested that, there is a functional difference between the activity of digestion by the digestive fluid in mid gut and tissue of mid gut. It has been reported by Horie et al., (1963) that, molecular proteins are hydrolyzed into peptides by digestive fluid content and into aminoacids with peptidases in the mid gut tissue. Likewise, the polysaccharides, are digested in the insect gut lumen by digestive fluid and disaccharides and/or trisaccharides get hydrolysed into their constituent monasaccharide sugars mainly in the gut tissue (Horie, 1967). Yamafugi and Yonezawa (1935) reported the analogy of insect lipase, the lipid digesting enzyme of the insect mid gut with pancreatic lipase of vertebrates. The attempts towards production of the qualitative silk through the improvement in the efficiency of consumption and utilization of food by larval instars of silkworm, Bombyx mori (L) include: improvement in the quality of mulberry leaves and supplementation of nutrient biocompounds like soya protein; potassium iodide, copper sulphate, other mineral salts, herbal products (or drugs) like digoxin (Vitthalrao and Kulkarni, 2011) kho-go (Desai et al., 2011) and stevia inulin (Shubhangi Pawar et al., 2017). Quality of mulberry leaves get reflected into the quality of the cocoons spun by fifth instar larvae of silkworm, Bombyx mori (L). There are reports on Use of soya protein; potassium iodide, copper sulphate, mineral salts, herbal products 
for improvement of the quality of leaves of mulberry, Morus alba. Herbal products are well known for the acceleration of metabolism in the body of larval instars of silkworm, Bombyx mori (L).

Sericultural practices are basically related to the nutrition and physiology of digestion in silkworm. Moreover, nutrition and physiology of digestion in silkworm are the most fundamental and important challenges in the sericulture. Significant sericulture may occur if and only if a species of silkworm can be grown quickly and economically. Distinguishing feature of larval instars of silkworm is digestion of albumin, fat and carbohydrates except cellulose (Kellner et al., 1887). The nutrient composition of the meal get reflect on ability of secretion of digestive enzymes in larval instars of silkworm. The leaves of mulberry, Morus alba (L) should be supplemented with various nutrients. This may help for silkworm feeding to promote silk quality and quantity (Mahmood et al., 2002).

Studies carried out by Mahmood et al., (2002) was reported significant consumption of food material followed by gain in the larval weight through feeding "Farm yard manure and ammonia solution" treated mulberry leaves. There is relation among factors like the nutritional status of mulberry leaves and silkworm growth, silk yield and disease resistance Ravikumar (1988). According to Sengupta et al., (1972), nutrients like essential sugars, amino acids, proteins and vitamins are obligatory for normal growth of larval instars of silkworm. Javed and Gondal (2002) have reported higher growth and lower mortality of silkworm larvae fed with nitrogen and ascorbic acid supplemented mulberry leaves. Kanekatsu (1972; 1978); Eguchi and Iwamoto (1976); Abraham (1992) and Sumida et al., (1994) studied on midgut digestive enzymes of larval instars of silkworm, Bombyx mori
(L). Kanekatsu et al., (1989) reported rationalization of some of midgut enzymes in larval instars of silkworm, Bombyx mori (L).

The Syzygium cumini (L) is a large evergreen tree, belong to family myrtacae. It is a medicinal plant. Various parts of this plant are used in controlling the diabetes like diseases. The fruits and the seeds of Syzigium are used in folk medicine. The seeds of syzigium are excellent source of glycosides. The flavonol glycosides have been isolated from the roots of this plant. In one of the earlier studies in author's laboratory, the glycosides are reported for the fortification of digestion in fifth instar larvae of silkworm, Bombyx mori (L). The seed powder of Syzigium cumini (L) is reported for contents of glycoside $(5,7-$ dihydroxy-6, 2 dimethoxyisoflavone-7-Oalpha-L-rhamnoside) in earlier studies in laboratory of present attempt holders. The aim of present attempt is to analyze the effect of feeding the leaves of mulberry, Morus alba (L) aqueous solution of seed powder of Syzigium cumini (L) on the velocity of biochemical reactions catalyzed by midgut protease and midgut amylase in the fifth instar larvae of silkworm, Bombyx mori (L).

\section{Materials and Methods}

The whole work in the attempt was divided into the steps like: Silkworm Rearing; Syzigium solution Preparation; Grouping the Fifth Instar Larvae; Treating the mulberry leaves and feeding the larvae; Protein Bioassay and Statistical analysis.

\section{Silkworm rearing}

The egg cards or disease free layings (DFL) of biivoltne, crossbreed race: [(CSR6 x CSR26)] x [CSR2 x CSR27)] of silkworm, Bombyx mori (L) were procured through the sericulture unit of Agriculture Development Trust, Malegaon. Black boxing was followed 
for incubation. The early age larvae (First and Second instared larvae) (Chawki) and late age larvae (Third; Fourth and Fifth instared larvae) were reared in the laboratory of "Dr. APIS" through the methods prescribed by Krishnaswami et al., (1978) and explained in earlier attempts by Khyade (2004); Vitthalrao and Kulkarni (2011); Desai et al., (2011) Shubhangi Pawar et al., (2017); Ramprakash Verma et al., (2018); Pranita Rajendra Vare et al., (2018); Manisha Mahendra Nalwade et al., (2018); Seema K. Dongare et al., (2018) and the others. The larvae were fed with fresh and appropriate quality leaves of mulberry, Morus alba (L) procured from sericulture unit at Malegaon Sheti Farm of Agricultural Development Trust Baramati, Shardanagar, (Malegaon Khurd). The schedule of feeding prescribed by Sharad G. Jagtap (2014) was followed for both early age larvae (First and Second instared larvae) (Chawki) and late age larvae (Third; Fourth and Fifth instared larvae). The fifth instared larvae were preferred for the analysis of effect of treating the mulberry leaves with aqueous solution of seeds of Syzigium cumini (L) and them for total protein contents.

\section{Syzigium solution preparation:}

The ripen fruits of Syzigium cumini (L) were collected from Malegaon Sheti Farm of Agricultural Development Trust Baramati, Shardanagar, (Malegaon Khurd). They were identified and confirmed for species through the Botanical Survey of India, Pune. Seeds were separated and allowed for shade drying. It was followed by preparation of seed powder through the use of domestic mixture. Known quantity of this powder was kept for maceration in distilled water for twenty four hours. Macerated content was allowed for filtration through muslin cloth. Volume of filtrate and weight of residue were accounted for knowing the strength of seed powder in the solution. The filtrate was further utilized for preparation of aqueous solution known strength. Four different concentrations of solution were prepared, which include: 10 ppm; 20 ppm; 40 ppm and 50 ppm.

\section{Grouping the fifth instar larvae}

Soon after the fourth moult, the the fifth instared larvae were divided into six groups, each with hundred individuals. The groups include: Untreated Control; Water treated Control and four treated groups. The four treated groups include: $10 \mathrm{ppm} ; 20 \mathrm{ppm} ; 40$ ppm and 50 ppm. $400 \mathrm{ml}$ of aqueous solution of seed powder was used to treat 100 grams of fresh mulberry leaves. The treatment was carried out for half an hour before feeding. The treated mulberry leaves were drained off completely and then fed to the fifth instar larvae of silkworm, Bombyx mori(L) in respective groups. Feeding treated mulberry was carried out for the first four days of fifth instars.

\section{Treating the mulberry leaves and feeding the larvae}

Mulberry leaf treatment was carried half an hour before each feeding. $2000 \mathrm{ml}$ of aqueous solution of seed powder of each strength was used to treat 500 grams of fresh mulberry leaves for feeding the group of hundred larvae for each time. Fresh leaves of mulberry, Morus alba (L) were weighed. The known volume of solution of each strength was taken in separate glass jar. Known quantity of mulberry leaves was kept immersed separately in aqueous solution of each strength. The treatment was carried out for half an hour before feeding. The treated mulberry leaves were drained off completely and then fed to the fifth instar larvae of silkworm, Bombyx mori (L) in respective groups. Four feedings were followed (5.00 a.m., 11.00 a.m. ; 5.00 p.m. ; 11.00 p.m.). Five hundred grams leaves of mulberry, 
Morus alba (L) were used for feeding the group of hundred larvae for each time. The feeding treated mulberry was carried out for the first four days of fifth instars. The larvae fed with untreated mulberry leaves and water treated mulberry leaves were also maintained.

\section{Bioassay of midgut Soluble Proteins; midgut protease and amylase}

The bioassay of midgut Soluble Proteins; midgut protease and amylase was carried out on fifth day of fifth instar. Twenty larvae from each group were selected randomly. Weight of individual larva was recorded. They were anaesthetized with chloroform soaked cotton pads. Individual larva was dissected open from dorsal side. The entire alimentary canal was separated from individual larva. The alimentary canal was flushed with ice cold saline so as to remove the debris of mulberry leaf and washed with ice cold saline. The alimentary canal was blotted and weighed accurately on electronic balance. The mid gut tissue was fragmented and then homogenized in chilled saline. Homogenate was centrifuged at $40^{\circ} \mathrm{C}$ for 15 min. at $10000 \mathrm{rpm}$. The supernatant was equalized to the volume, aliquots of which contain $10 \mathrm{mg}$ per $\mathrm{ml}$ and used as assay sample. Half the volume of assay sample was utilized for bioassay of soluble proteins and another half for mid gut enzymes (protease and amylase).

Bioassay of soluble proteins was carried out through the methods of Lowery et al., (1951). For each assay sample (of each group), bioassay was carried in the triplicate set. One $\mathrm{ml}$ of assay sample was added in each test tube. The blank test tube was also prepared simultaneously, in which the assay sample was replaced with distilled water. Addition of $5 \mathrm{ml}$ Lowery's "C" solution was made in each test tube, mixed well and kept for 15 minutes for the purpose to form the copper-protein complex. After fifteen minutes; $0.5 \mathrm{ml}$ Folin's phenol reagent was added in each test tube and mixed well. The content in each test tube was allowed to develop colour. Then the optical density of content of each test tube was recorded at $660 \mathrm{~nm}$ on spectrophotometer. The concentration of soluble proteins of each assay sample was calculated through the reference of optical density assay sample and standard proteins (BSA) (the plot of optical density against concentration of BSA).

The activity of mid gut protease was carried out according to the method of Brik et al., (1962) with modifications suggested by Isshaya et al., (1971) and outlined by Chougale (1992) and Khyade (2004). The mid gut protease activity was determined in triplicate set along with the blank. The mixture of incubation consisted of substrate (one $\mathrm{ml}$ of ten percent casein solution); source of enzyme $(0.5 \mathrm{ml}$ assay sample $)$ and $0.5 \mathrm{ml}$ of $0.2 \mathrm{M}$ Trisbuffer $(\mathrm{pH}=8.4)$. For the blank, assay sample was replaced by distilled water. The incubation was carried out in water bath at $30^{\circ} \mathrm{C}$ for 20 minutes with constant shaking. Addition of $6 \mathrm{ml}$ of 2 percent trichloroacitic acid was made.

The content was centrifuged at $8000 \mathrm{rpm}$ for 15 minutes. The supernatant was used to read the optical density at $280 \mathrm{~nm}$ on spectrophotometer. Amount of tyrosine liberated from the casein due to action of mid gut protease was calculated through the use of optical density readings for assay sample; tyrosine (from standard graph) and predetermined soluble protein contents of each assay sample. The activity of mid gut protease was expressed in terms of specific activity: microgram tyrosine liberated per $\mathrm{mg}$ protein per minute.

The activity of mid gut amylase was determined according to the methods of Bernfeld (1955); explained by Ishaaya and Swirski (1970), with modifications suggested 
by Gaikwad (1998) and outlined by Khyade (2004) and Desai et al., (2011). For the purpose to determine the activity of mid gut amylase, 20 larvae were selected randomly and processed for assay sample preparation as described for soluble proteins. Mid gut amylase was determined in triplicate set along with blank. The incubation mixture consisted of one $\mathrm{ml}$ of one percent starch solution (as substrate), phosphate buffer $(\mathrm{pH}=9.2)$ and 0.5 $\mathrm{ml}$ of assay sample.

For the blank, assay sample was replaced by distilled water. The process of incubation was carried out in water bath at $30^{\circ} \mathrm{C}$ for 20 minutes. After incubation the termination of activity of enzyme was made by addition of 2 $\mathrm{ml}$ DNSA and $2 \mathrm{ml}$ distilled water. The contents were heated in boiling water bath exactly for five minutes, cooled immediately and the optical density of content was read at $540 \mathrm{~nm}$ on spectrophotometer.

For the purpose to calculate the mid gut amylase activity; the optical density readings for each assay sample; standard solution of maltase (from graph) and soluble proteins were utilized. The enzyme activity was expressed in specific activity: micrograms of maltose liberated per $\mathrm{mg}$ protein per minute.

\section{Statistical analysis}

Consistency in the results is qualitative parameter in research studies. Therefore, the whole experimentation in the present study was repeated for thrice. The data of all the three attempts was collected and subjected for statistical analysis. The statistical parameters for analysis considered in the study include mean, standard deviation, percent change and significance through student $t-$ test introduced by William Sealy Gosset (a chemist working for the Guinness brewery in Dublin, Ireland. "Student" was his pen name) (https://en.wikipedia.org/wiki/Student\%27s_t- test) and explained by Norman and Baily (1955).

\section{Results and Discussion}

The results on the effect of feeding the leaves of mulberry, Morus alba (L) aqueous solution of seed powder of Syzigium cumini (L) on the velocity of biochemical reactions catalyzed by midgut protease and midgut amylase in the fifth instar larvae of silkworm, Bombyx mori (L). are summarized in table 1 and presented in Figure 1 and 2. Treating the mulberry leaves with various concentrations of aqueous solution of Syzigium seed powder and feeding them to the fifth instar larvae of silkworm, Bombyx mori (L) for four days was found variously reflected in the levels of activity of enzymes (protease and amylase) in the mid gut tissue homogenate.

The velocity of biochemical reaction catalyzed by mid gut protease and midgut amylase in larvae fed with untreated mulberry leaves was found measured 02.593 units and 5.547 units respectively. The midgut protease activity in larvae fed with mulberry leaves treated with various concentrations (10.0 ppm; $20.0 \mathrm{ppm} ; 40.0 \mathrm{ppm}$ and $50.0 \mathrm{ppm}$ ) of the aqueous solution of seed powder of Syzigium cumini (L) was found measured $3.217 ; 4.339 ; 4.476$ and 5.793 units respectively. The midgut amylase activity in larvae fed with mulberry leaves treated with various concentrations $(10.0 \mathrm{ppm} ; 20.0 \mathrm{ppm}$; $40.0 \mathrm{ppm}$ and $50.0 \mathrm{ppm}$ ) of the aqueous solution of seed powder of Syzigium cumini (L) was found measured 6.864; 10.148; 10.319 and 10.483 units respectively. Percent increase in the midgut protease activity through Syzigium treatment in present attempt was ranging from 24.064 to 123.41 (Table 1). Percent increase in the midgut amylase activity through Syzigium treatment in present attempt was ranging from 23.742 to 88.985 (Table 1). 
Table.1 The activity of mid gut protease and mid gut amylase in the fifth instar larvae of silkworm, Bombyx mori (L) (Race: Bivoltine Cross Breed [(CSR6 x CSR26) x CSR2 x CSR27)] fed with the leaves of mulberry, Morus alba (L) (M-5: variety) treated with aqueous solution of seed powder of Syzigium cumuni (L)

\begin{tabular}{|l|l|l|}
\hline Mid Gut Enzymes & Protease & Amylase \\
\hline Group & & \\
\hline Untreated Control & 02.593 & 5.547 \\
& $( \pm 0.274)$ & $( \pm 0.816)$ \\
& 00.000 & 00.000 \\
\hline $\mathbf{1 0} \mathbf{~ p p m}$ & $3.217^{*}$ & $6.864^{*}$ \\
& $( \pm 0.695)$ & $( \pm 1.213)$ \\
& 24.064 & 23.742 \\
\hline $\mathbf{2 0} \mathbf{~ p p m}$ & $4.339^{* *}$ & $10.148^{* *}$ \\
& $( \pm 1.107)$ & $( \pm 2.321)$ \\
& 67.335 & 82.945 \\
\hline $\mathbf{4 0} \mathbf{~ p p m}$ & $4.476^{* * *}$ & $10.319^{* * *}$ \\
& $( \pm 1.786)$ & $( \pm 3.312)$ \\
& 72.618 & 86.028 \\
\hline $\mathbf{5 0} \mathbf{~ p p m}$ & $5.793^{* * *}$ & $10.483^{* * *}$ \\
& $( \pm 2.011)$ & $( \pm 3.786)$ \\
& 123.41 & 88.985 \\
\hline
\end{tabular}

Each figure is the mean and three replications.

- $\quad$ Figure in parenthesis with \pm sign is the standard deviation.

- $\quad$ Figure below parenthesis is percent change.

$\begin{array}{lll}* & : & \mathrm{P}<0.05 \\ * * & : & \mathrm{P}<0.01 \\ * * * & : & \mathrm{P}<0.001\end{array}$

Fig.1 The activity of mid gut protease in the fifth instar larvae of silkworm, Bombyx mori (L) (Race: Bivoltine Cross Breed [(CSR6 x CSR26) x CSR2 x CSR27)] fed with the leaves of mulberry, Morus alba (L) (M-5: variety) treated with aqueous solution of seed powder of Syzigium cumuni (L)

6

4

2

0

UT Control 10 ppm
20 ppm

40 ppm
50 ppm 
Fig.2 The Activity of Mid Gut Amylase in the Fifth Instar Larvae of Silkworm, Bombyx mori (L) (Race: Bivoltine Cross Breed [(CSR6 x CSR26) x CSR2 x CSR27)] Fed With the Leaves of Mulberry, Morus alba (L) (M-5: variety) Treated With Aqueous Solution of Seed Powder of Syzigium cumuni (L)

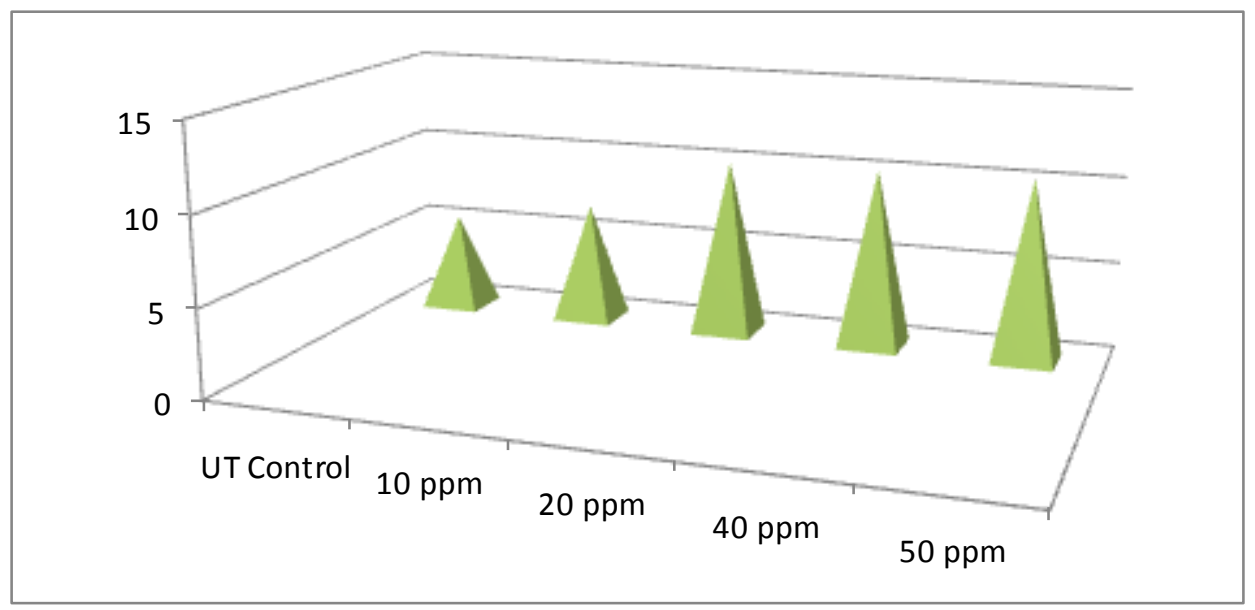

Significant improvement in the activities of midgut protease and amylase in the larval instars of silkworm, Bombyx mori (L) (Race: Bivoltine Cross Breed [(CSR6 x CSR26) x CSR2 x CSR27)] fed with the leaves of mulberry, Morus alba (L) (M-5: variety) treated With aqueous solution of seed powder of Syzigium cumuni (L) may be explained away as due to enhanced break down of contents of mulberry leaves. Some of the herbal powders contain insect juvenoids (like eugenol) are known to increase the capability of consumption and utilization of food by larval instars of insects like silkworm. The contents of seeds of Syzigium cumini (L) may have had such capabilities. This may be responsible for improve appetite and digestion.

According to Sen (1988), the plant derived compounds, in phytophagous insects, mimic the action of natural juvenile hormone, which enhance the synthesis of poly (A) RNA for major silk protein. Most significant response for Syzigium treatment in the study seems to be the levels of mid gut protease and mid gut amylase. The enzymes belongs to soluble proteins. The soluble proteins contribute in the tissue metabolism through enzymes. According to Applebaum (1985), continuous feeding in insects get reflect into advancement of production of mid gut enzymes, which improve the enzyme efficiencies. Most significant improvement in the protease activity in the treated group of study may be concerned with contents of specific plants. Individual plant extractive treatment may screen out the plant responsible for improved protease activity. Likewise the amylase enhancing herbal constituents of herbal formulations should be screened.

Feeding treated mulberry leaves for first four days possibly availing the herbal nutrients, which affect digestibility of larvae and may contribute phyto-juvenoids or other compounds of growth and development. The study should be extended for screening juvenoid activity of Syzigium seed powder.

\section{Acknowledgement}

Academic support received from International Science Community Association (ISCA) and Agriculture Development Trust, Baramati 
deserve appreciation and exert salutary influence.

\section{References}

Abraham E G, Nagaraju J, Datta RK. Chemical studies of amylases in the silkworm, Bombyx mori L Comparative analysis in diapause and nondiapause strains. Insect Biochem Mol Biol. 1992; 22: 867-873.

Applebaum, S.W. (1985). Biochemistry of digestion. In: Comprehensive insect physiology (Ed. Kerkut, G.A. and Gilbert (I), 4:297-307. Pergamon press New York.

Apurva Baban Tamhane; Mansi Avinash Adagale; Shubhangi Shankar Pawar and Vitthalrao B Khyade (2017). Influence of Stevia Inulin Treated Leaves of mulberry, Morus alba (L) on the midgut enzymes in the fifth instar larvae of silkworm, Bombyx mori (L) (Race: PM x $\mathrm{CSR}_{2}$ ). International Journal of Agricultural Sciences and Veterinary Medicine Vol. 5; No. 4; November, 2017: $22-30$. http://www.ijasvm.com/ ijasvmadmin/upload/IJASVM_5a0573eb3d129. pdf

Bernfeld, P. (1955). Amylase, a and b. In: Methods of Enzymology, Vol.I (Ed. Clockwik and Kalpin). Academic Press, New York.

Bowers, W.S., Fales, V.M., Thompson, M.J. and Uebel,B.(1966). Juvenile and gonadotropic activity of 10,11 epoxyfranesoic acid methyl ester. Life Science. 4: 2323-2331.

Brik, Y., Harpaz,J. ; Ishaya and Bhondi, A.(1962), Studies on proteolytic activity of beetle, Tenebrio molitor (L). J. Insect Physiol. 8: 417429.

Chougale, A.C.(1992). Influence of magnetic energy on silkworm, Bombyx mori (L). Ph.D. Thesis, Shivaji University, Kolhapur.

Desai, V.A., Pawar, V.V. and Sawant, R.T.(2011). Influence of herbal drug: kho-go on the fifth instar larvae of silkworm, Bombyx mori (L).Dissertation in the partial fulfillment of M.Sc. (Microbiology), Shardabai Pawar Mahila College, Shardanagar (Baramati), (Pune University, Pune).

Eguchi M, Iwamoto A. Alkaline protease in the midgut tissue and digestive fluid of silkworm, Bombyx mori L. Insect Biochem. 1976; 6: 491496.

Gaikwad, A.R.(1998). Biology of some dung beetles of South Western Maharashtra. Ph.D. thesis, Shivaji University, Kolhapur.

Gauri U. Kadam and Vitthalrao B. Khyade (2013): Effect of age and sex on the activity of protease in the mid gut and integument of fifth instar silk worm, Bombyx mori (L) (Race: PM x CSR2). International Journal of Advanced Biological Research (Society for Science and Nature). Vol. 3(2)2013: 188 - 190. www.scienceandnature.org

Ghantaloo, U.S. (2007). Influence of digoxin on silkworm, Bombyx mori (L). M.Phil. Thesis, Algappa University, Karaikudi (Tamil Nadu), India.

Horie, Y. (1961). Physiological studies on the limentary canal of silkworm, Bombyx mori (L).III. Absorption and utilization of carbohydrates. Bull. Sericult. Exp. Sta. Japan, 16: 287-309.

Horie, Y., Tanaka,M. and Ito,T. (1963). Proteolytic enzyme of digestive juice of mid gut in silkworm, Bombyx mori (L). J. Setricult. Sci. Japan, 32: 8-15.

Ishaaya, I., Moore, I and Joseph, B.(1971). Protease and amylase activity in the larvae of Egyptian cotton worm, Spodoptera littoralis (L). J. Insect physiol. 17: 945-953.

Ishaya,I. and Swirski, E. (1976). Trehalase, invertase and amylase activities in the larvae of Egyptian cotton worm, Spodoptera littoralis (L). J. Insect Physiol. 17: 945-953.

Ito, H. (1960). Effect of sugars on feeding the larvae of silkworm, Bombyx mori (L) J. Insect. Physiol. Vol.5: 95-107.

Ito, T.(1961). Nutrition of silkworm, Bombyx mori (L). Proc. Jpn. Acad. Sci. 43:57-61.

Ito, T; Kwashima, K., Nakhara,M., Nakanshi, K. and Terahara,A.(1964). Metabolism in the mid gut of silkworm, Bombyx mori (L). Insect Physiol. Vol.10: 225-228.

Jagtap, S.G.(2007). Effect of plant juvenoids on consumption and utlizationof mulberry leaves by silkworm, Bombyx mori (L). M.Phil. Thesis, Algappa University, Karaikudi, Tamil Nadu, (India).

Javed H, Gondal MH. Effect of food supplementation by $\mathrm{N}$ and Ascorbic Acid on larval mortality of silkworm (Bombyx mori L). Asian journal of plant science. 2002; 1(5): 556557.

Kanekatsu R, Ichimura H, Hori M. Distribution and developmental changes in midgut sucrase activity of the silkworm, Bombyx mori. J Seri 
Sci Japan. 1989; 58: 517-523

Kanekatsu R. Amylase in the digestive juice of silkworm larvae, Bombyx mori. J Seric Sci. 1972; 41: 445-451.

Kanekatsu R. Studies on further properties for an alkaline amylase in the digestive juice of silkworm, Bombyx mori. J Fac Text Sci Technol. 1978; 76: 1-21.

Kellner 0, Kakizaki S, Matsuoka M, Yoshu T. XXIV. On the physiology of the silk workm. By Alexander pringle jameson and william ringrose gelston atkins. Landw. Versuchsstationen. 1887; 33: 38.

Khyade V. B. ;Gaikwad D. R. and Thakare U. G. (2012). Utilization of Aloe vera $(\mathrm{L})$ Herbal Tonic for Treating Mulberry Leaves before feeding the Fifth Instar Larvae of Silkworm, Bombyx mori(L) (Race: PM x CSR2) (Editor: Dr. A. R. Tuwar and Dr. M. J. Shaikh Dept. of Life Sciences, Arts and Science College, Sonai Tal. Newasa, Dist. Ahmednagar - 414105 India): $37-40$.

Khyade, V.B.(2004). Influence of juvenoids on silkworm, Bombyx mori (L). Ph.D. thesis, Shivaji University, Kolhapur.

Krishnaswami,S., Narasimhna, M.N., Suryanarayana, S.K. and Kumararaj, S.(1978). Sericulture Manual-II Silkworm Rearing: FAO. United Nations Rome.

Lowery, O.H., Rosenbrough, N.J., Far,A.L. and Randall, R.J.(1951). Protein measurement with folin phenol reagent. J. Biol. Chem. 193: 265275.

Mahmood R, Jan MT, Khan MI, Effect of nitrogen (farmyard manure + urea) treated mulberry trees on the larval development and cocoon weight of silkworm, Bombyx mori L Asian J plant Sci. 2002; 2 (1): 93-94.

Manisha Mahendra Nalwade; Kajal Appasaheb Pondkule; Trupti Nandkumar Gaikwad and Vitthalrao Bhimasha Khyade (2018). Treating the leaves of mulberry, Morus alba (L) with aqueous solution of seed powder of cowpea, Vigna unguiculata (L) and feeding fifth instar larvae of silkworm, Bombyx mori (L) for the fortification of the cocoon and silk filament. 2018 IJSRST | Volume 4 | Issue 2 Themed Section: Science and Technology Pages: $1277-$ 1288. www.ijsrst.com

Monika Patil and Vitthalrao B. Khyade(2017).Treating The Leaves Of Mulberry, Morus alba (L) With Aqueous Solution Of Seed Powder Of Cowpea, Vigna unguiculata (L) And Feeding Fifth Instar Larvae Of Silkworm, Bombyx mori (L) (Race: $\mathrm{Pm}$ X Csr2) For The Fortification Of The Cocoon And Silk Filament. International Academic Journal of Innovative Research Vol. 4, No. 1, 2017, pp. 41-50. www.iaiest.com

Murali, K.(1992).Effect of leaf carbohydrate reserves on the growth and excretory pattern of silkworm, Bombyx mori (L). M.Phil. Dissertation, Sri. Venkateshwara University, Tirupati (India).

Murugan, K.and George, A. (Sr.)(1992). Feedings and nutritional influence on growth and reproduction of Daphnia near (L). Insect Physiol. 38: 961-969.

Nayar, J.K. and Frankel,G.(1962). Journal of Insect Physiology. Volume-8, page-505.

Norman, T.J. and Baily (1955). Statistical methods in Biology.

Pranita Rajendra Vare., Seema Karna Dongare and Vitthalrao Bhimasha Khyade (2018). Quality Of The Cocoons And Silk Filament Obtained From The Larvae Of Silkworm, Bombyx mori (L) (Race: Bivoltine Double Hybrid [(Po3 $\times$ $\mathrm{Nd} 5) \times(\mathrm{Csr} 4 \times \mathrm{Csr} 2)]$ Fed With The Leaves Of Mulberry, Morus Alba (L) (M-5: Variety) Treated With Aqueous Solution Of Maple Syrup Belong To Acer Saccharum (L)', International Journal of Current Innovation Research, 4(3), pp. 1095-1100. www.journalijcir.com http://journalijcir.com/issues/quality-cocoonsand-silk-filament-obtained-larvae-silkwormbombyx-mori-l-race-bivoltine

Ravikumar C. Western ghat as a bivoltine region prospects, challenges and strategies for its development. Indian Silk. 1988; 26(9): 39-54.

Sengupta K, Singh B.D, Mustafij C. Nutrition of silkworm. Bombyx mori L.I. Studies on the enrichment of mulberry leaf with various sugars, proteins, aminoacids and vitamins for vigorous growth of the worm and increased cocoon crop production. Indian J Sci. 1972; 11:11-27.

Sharad G. Jagtap; Vitthalrao B. Khyade and Santoshrao G. Mali (2015). Influence of Treating the mulberry leaves with aqueous maceratives of seed powder of Syzigium cumini (L) on the activities of digestive enzyme in the fifth instar larvae of silkworm, Bombyx mori (L) (Race: PM x CSR2). Elixir International Journal Applied Zoology / Elixir Appl. $\begin{array}{llll}\text { Zoology } & 85 & \text { (2015) 34140-34144. }\end{array}$ 
www.elixirpublishers.com(Elixir.International.J ournal.Applied.Zoology

Shubhangi Shankar Pawar and Vitthalrao B Khyade (2017). Use of leaves of mulberry, Morus alba (L) treated with Stevia Inulin for the improvement of activities of enzymes in the mid gut protease and amylase of the last stage silkworm larvae. International Research Journal of Biological Sciences Vol. 6(11), 24-30, November (201 7): $24-30$.

Slansky, F. and Scriber, J.M. (1985). Food consumption and Utilization. In: comprehensive Insect physiology, Biochemistry and pharmacology. (Eds. Kerkut, G.A. and Gilbert, L.I.) 4, Pergamon Press, Oxford, Page: 639.

Subramanyam Reddy, C.(1992).Studies on distribution of digestive enzymes in the digestive tract of silkworm, Bombyx mori (L). M.Phil. Dissertation, Sri. Venkateshwara University, Tirupati (India).

Sucheta S. Doshi ; Anil N. Shendage and Vitthalrao B. Khyade (2014): Utilization of Digixin the herbal product for treating the mulberry leaves and feeding the fifth instar larvae of silkworm, Bombyx mori (L) (Race: PM x CSR2). Standard Global Journal of Scientific Research Vol. 1 (2): $020 \quad-024$ March 2014. http://www.standardglobaljournals.com/journal s/SGJSR/2014/march/Doshi\%20et\%20al.html

Sumida M, Yuan X L, Matsubara F. Sucrase activity and its kinetic properties in pertrophic membrans, and in membrane-bound and soluble fractions of midgut in silkworm, Bombyx mori L Comp Biochem Physiol. A 1994; 108: 255-264.

Vitthalrao B. Khyade (2014): Influence of Lanoxin Treared Mulberry Leaves on the contents of proteins in the fifth instar larvae of silkworm, Bombyx mori (L) (Race: PM x CSR2). 2014. (Page: 8 - 17). Proceeding, Two day UGC sponsored National seminar on, "Recent Trends in Cell Biology, Biotechnology and Bioinformatics", Organized by Department of Zoology, Balwant College, Vita Tal. Khanapur, Dist. Sangli 415311 (India) (6 and 7 September, 2013). Editor: Prof. (Smt.) U. H. Shah (Department of Zoology, Balwant College, Vita).

Vitthalrao B. Khyade and Jyoti Kulkarni (2011). Effect of digoxin treated mulberry leaves on protein profiles in fifth instar larvae of silkworm, Bombyx mori (L) (PM x CSR 2$)$. Res.
J. Chem. Sci. Vol.1 (1): 2-7 (www.isca.in)

Vitthalrao B. Khyade (2005). VividhVanaspati Arkancha Tuti Reshim Kitak Sangopanasathi Upyojan. KrishiVidnyan 4: $18-22$.

Vitthalrao B. Khyade (2016). Utilization of mulberry leaves treated with seed powder of cowpea, Vigna unguiculata (L) for feeding the fifth instar larvae of silkworm, Bombyx mori (L) (Race: PM x CSR2). Journal of Medicinal Plants Studies 2016; 4(3): 182 - 188. http://www.plantsjournal.com/archives/2016/vo 14issue3/PartC/4--2-33-339.pdf

Vitthalrao B. Khyade and Atharv Atul Gosavi (2016).Utilization of mulberry leaves treated with seed powder cowpea, Vigna unguiculata (L) for feeding the fifth instar larvae of silkworm, Bombyx mori (L) (Race: PM x CSR2). World Scientific news 40 (2016): 147162. www.worldscientificnews.com.

Vitthalrao B. Khyade and Jiwan P. Sarawade (2013). Glycosides from the seed powder of Syzigium cumini (L). Annals of Plant Sciences 2 (1): 46 48. www.annalofplantsciences.com

Vitthalrao B. Khyade and Jiwan P. Sarwade (2013): Glycoside from the seed powder of Syzigium cumini (L). Journal of Association of Zoologists India Vol. 6 No. 1 (March 2013): 91 $-96$.

Vitthalrao B. Khyade and Jiwan P. Sarwade (2013): Utilization of Digoxin, the herbal product for treating the mulberry leaves and feeding the fifth instar larvae of silkworm, Bombyxmori (L) (Race: PM x CSR2). 2013 International Journal of Multidisciplinary Research (IJMR) Vol. I / Issue 12 (III): 38-42.

Vitthalrao B. Khyade and Rajkumar B. Deshmukh (2015). Mid gut protease and amylase activity in the fifth instar larvae of silkworm, Bombyxmori (L) (Race: PM x CSR2) fed with mulberry leaves treated with aqueous solution of stevia inulin powder. Proceedings, U G C Sponsored National Conference on Recent Trends in Life Sciences (10 - 11, July, 2015), organized by Department of Zoology, S. M. Joshi College, Pune. Pp: 95 - 106.

Vitthalrao B. Khyade and Sucheta S. Doshi (2012). Protein Contents and activity of enzymes in the mid gut homogenate of fifth instar larvae of silk worm, Bombyx mori (L) (Race: PM x CSR2) fed with herbal drug (Kho Go) treated mulberry leaves. Research Journal of Recent Sciences Vol. 1 (2): 49 - 55. www.isca.in.

Vitthalrao B. Khyade and Vivekanand V. Khyade 
(2013): Plants: The Source of Animal Hormones. "Frontiers in Life sciences", the book published by Science Impact Publication, Ahmedpur (Latur) - 413515 (India): 151 - 168. Editor: Dr. SayyedIliyasUsman (Poona College, Camp Pune).

Vitthalrao B. Khyade (2012). Isolation of glycoside from the seed powder of Syzigium cumini $(L)$. International Journal of Bioassays (IJB) 01 (12): $207-209$ www.ijbio.com.

Vitthalrao B. Khyade; and Jiwan P. Sarawade (2012). Contents of protein and activity of protease and amylase in the mid gut homogenate of fifth instar larvae of Bombyx mori L. (PM x CSR2) fed with herbal drug(Kho-Go) treated mulberry leaves. International Journal of Science and Nature $\begin{array}{lllll}\text { Vol.3 (3): } \quad 526 & - & 530\end{array}$ www.scienceandnature.org.

Vitthalrao B. Khyade; Poonam M. Patil; Kalyani R. Jaybhay; Rasika G. Gaikwad; Ganga V. Mhamane; Vivekanand V. Khyade; Kavita H. Nimbalkar and Sneha G. Jagtap (2007). Effect of digoxin on mid gut glucosidase activity in silkworm, Bombyxmori (L). Journal of Zoological Society of India: Bioinformatics: 32 - 48. (Editors: B. N. Pandey; SadhanaDeshpande; A. K. Triphathi and A. D. Adsool) (Publisher: A $\mathrm{P} \quad \mathrm{H}$ Publishing Corporation, New Delhi).

Vitthalrao B. Khyade; Sakharam B. Patil ;Sunanda V. Khyade and Ganesh P. Bhawane (2002).
Influence of Acetone maceratives of Vitis vinifera on larval parameters of silkworm, Bombyx mori (L). Indian Journal of Comparative Animal Physiology Vol. 21 (1): $14-18$.

Vitthalrao B. Khyade; Sakharam B. Patil ;Sunanda V. Khyade and Ganesh P. Bhawane (2003). Influence of Acetone maceratives of Vitis vinefera on economic parameters of silkworm Bombyx mori (L).Indian Journal of Comparative Animal Physiology Vol. 21 (1): $28-32$.

Vitthalrao Bhimasha Khyade and Brij Kishore Tyagi (2018). Paratransgenesis Involving Microbes: A New Avenue for the Control of VectorBorne Diseases. Book: "Microbial Control of Vector-Borne Diseases" Editor: Brij Kishore Tyagi and Dharumadurai Dhanasekaran. International Standard Book Number-13: 9781-138-05581-0 (Hardback). Publisher: Taylor and Francis Group, Section - I (Microbial Control of Mosquito Vector) Page No. 167 179.

http://tylorandfrancis.com http://www.taylorandfrancis.com

Vitthalrao Khyade and Jeevan P. Sarawade (2009) protein profiles in the fifth instar larvaeof silkworm, Bombyx mori (L)(PM xCSR 2 ) fed with digoxin treated mulberry leaves. The Bioscan(1): 41-44.

Yamafuji, I. and Yonezawa(1935). Lipases in silkworm, Bombyx mori (L).Insect. Biochem. 1: 102-112.

\section{How to cite this article:}

Dipali Anil Ajage, Amruta Sanjay Tambe, Supriya Sunil Pawar and Vitthalrao B. Khyade. 2019. Protein and Carbohydrate Digesting Capability of Syzigium Seed Powder in the Tissue Homogenate of Mid Gut in the Fifth Instar of Silkworm, Bombyx mori (L) Race: Bivoltine Cross Breed [(CSR6 x CSR26) x CSR2 x CSR27)]. Int.J.Curr.Microbiol.App.Sci. 8(01): 23432354. doi: https://doi.org/10.20546/ijcmas.2019.801.246 